Prepared in cooperation with the City of Wichita, Kansas

\title{
Status of Groundwater Levels and Storage Volume in the Equus Beds Aquifer near Wichita, Kansas, January 2016
}

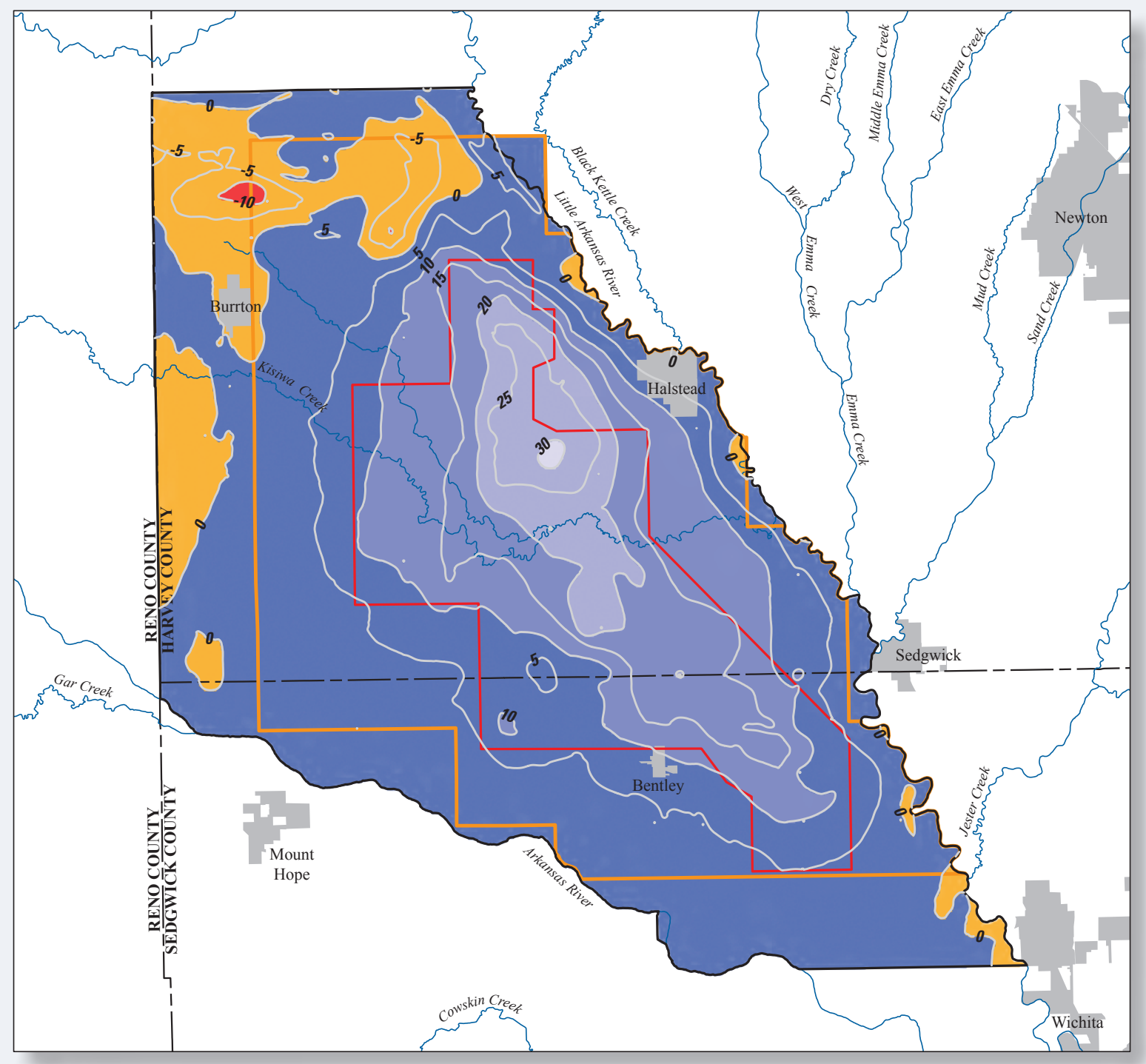

Scientific Investigations Report 2016-5165 
Cover. Figure 8 from this report. 


\section{Status of Groundwater Levels and Storage Volume in the Equus Beds Aquifer near Wichita, Kansas, January 2016}

By Brian J. Klager

Prepared in cooperation with the City of Wichita, Kansas

Scientific Investigations Report 2016-5165 


\title{
U.S. Department of the Interior SALLY JEWELL, Secretary
}

\section{U.S. Geological Survey Suzette M. Kimball, Director}

\author{
U.S. Geological Survey, Reston, Virginia: 2016
}

For more information on the USGS - the Federal source for science about the Earth, its natural and living resources, natural hazards, and the environment—visit http://www.usgs.gov or call 1-888-ASK-USGS.

For an overview of USGS information products, including maps, imagery, and publications, visit http://store.usgs.gov.

Any use of trade, firm, or product names is for descriptive purposes only and does not imply endorsement by the U.S. Government.

Although this information product, for the most part, is in the public domain, it also may contain copyrighted materials as noted in the text. Permission to reproduce copyrighted items must be secured from the copyright owner.

Suggested citation:

Klager, B.J., 2016, Status of groundwater levels and storage volume in the Equus Beds aquifer near Wichita, Kansas, January 2016: U.S. Geological Survey Scientific Investigations Report 2016-5165, 15 p., https://doi.org/10.3133/ sir20165165.

ISSN 2328-0328 (online) 


\section{Acknowledgments}

The author acknowledges the assistance of staff of the city of Wichita and the staff of Equus Beds Groundwater Management District No. 2 for collecting and providing groundwater-level data used in this report.

Technical reviews provided by U.S. Geological Survey employees Virginia McGuire and Brian Kelly improved the technical and editorial clarity of this report. 



\section{Contents}

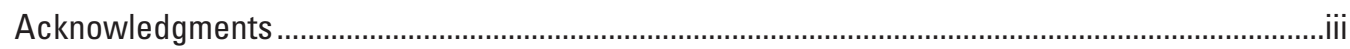

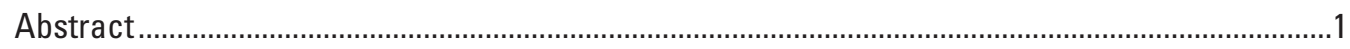

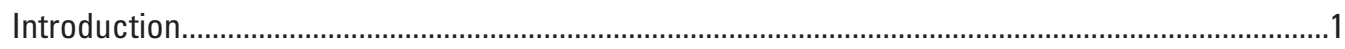

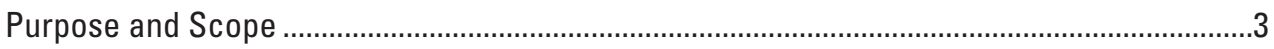

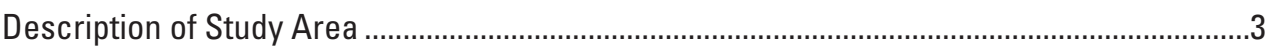

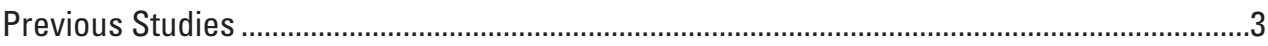

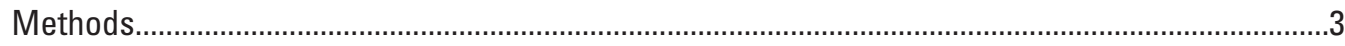

Groundwater-Level Measurements................................................................................

Shallow and Deep Parts of the Aquifer............................................................................ 4

Interpolation of Potentiometric Surfaces ...........................................................................

Estimation of Storage-Volume Change ………..................................................................

Potentiometric Surface Maps, January 2016 ...........................................................................

Groundwater-Level and Storage-Volume Changes in the Equus Beds Aquifer................................

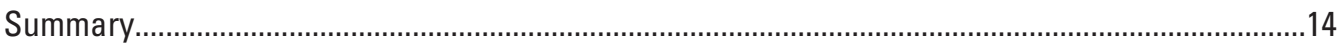

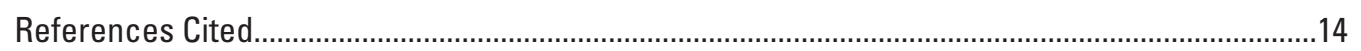

\section{Figures}

1. Map showing location of the study area near Wichita, Kansas .......................................2

2. Graph showing annual groundwater use in the central Wichita well field area and the rest of the study area, and average annual precipitation in the study area, 1988

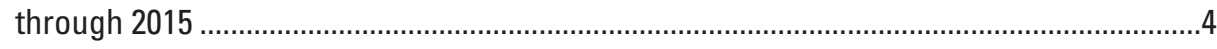

3. Map showing potentiometric surface of the shallow part of the Equus Beds aquifer study area, south-central Kansas, January 2016 ...........................................................

4. Map showing potentiometric surface of the deep part of the Equus Beds aquifer study area, south-central Kansas, January 2016 ...........................................................7

5. Map showing groundwater-level change in the shallow part of the Equus Beds aquifer study area in south-central Kansas, January 2015 to January 2016.....................8

6. Graph showing estimates of storage-volume change since predevelopment and 1993 in the Equus Beds aquifer study area ...............................................................10

7. Map showing groundwater-level changes in the Equus Beds aquifer in and around the Wichita well field in south-central Kansas between predevelopment and the historic low of 1993

8. Map showing groundwater-level changes in the shallow part of the Equus Beds aquifer in and around the Wichita well field in south-central Kansas between 1993 and January 2016

9. Map showing groundwater-level changes in the shallow part of the Equus Beds aquifer in and around the Wichita well field in south-central Kansas between predevelopment and January 2016

\section{Tables}

1. Storage-volume changes in the Equus Beds aquifer near Wichita, Kansas, since predevelopment and since 1993 to January 2016 for the study area, the basin storage area, and the central Wichita well field area. 


\section{Conversion Factors}

U.S. customary units to International System of Units

\begin{tabular}{|c|c|c|}
\hline Multiply & By & To obtain \\
\hline \multicolumn{3}{|c|}{ Length } \\
\hline inch (in.) & 2.54 & centimeter $(\mathrm{cm})$ \\
\hline inch (in.) & 25.4 & millimeter $(\mathrm{mm})$ \\
\hline foot $(\mathrm{ft})$ & 0.3048 & meter $(\mathrm{m})$ \\
\hline \multicolumn{3}{|c|}{ Area } \\
\hline square mile $\left(\mathrm{mi}^{2}\right)$ & 259.0 & hectare (ha) \\
\hline square mile $\left(\mathrm{mi}^{2}\right)$ & 2.590 & square kilometer $\left(\mathrm{km}^{2}\right)$ \\
\hline acre & $4,046.86$ & square meter $\left(\mathrm{m}^{2}\right)$ \\
\hline acre & 0.00404686 & square kilometer $\left(\mathrm{km}^{2}\right)$ \\
\hline acre & 0.404686 & hectare (ha) \\
\hline \multicolumn{3}{|c|}{ Volume } \\
\hline acre-foot (acre-ft) & 1,233 & cubic meter $\left(\mathrm{m}^{3}\right)$ \\
\hline acre-foot (acre-ft) & 0.325851 & million gallons (Mgal) \\
\hline \multicolumn{3}{|c|}{ Flow rate } \\
\hline acre-foot per year (acre-ft/yr) & 1,233 & cubic meter per year $\left(\mathrm{m}^{3} / \mathrm{yr}\right)$ \\
\hline
\end{tabular}

Temperature in degrees Celsius $\left({ }^{\circ} \mathrm{C}\right)$ may be converted to degrees Fahrenheit $\left({ }^{\circ} \mathrm{F}\right)$ as follows:

${ }^{\circ} \mathrm{F}=\left(1.8 \mathrm{x}^{\circ} \mathrm{C}\right)+32$

Temperature in degrees Fahrenheit $\left({ }^{\circ} \mathrm{F}\right)$ may be converted to degrees Celsius $\left({ }^{\circ} \mathrm{C}\right)$ as follows:

$$
{ }^{\circ} \mathrm{C}=\left({ }^{\circ} \mathrm{F}-32\right) / 1.8
$$

Vertical coordinate information is referenced to the North American Vertical Datum of 1988 (NAVD 88).

Horizontal coordinate information is referenced to the North American Datum of 1983 (NAD 83). 


\title{
Status of Groundwater Levels and Storage Volume in the Equus Beds Aquifer near Wichita, Kansas, January 2016
}

\author{
By Brian J. Klager
}

\section{Abstract}

The Equus Beds aquifer in south-central Kansas, which is part of the High Plains aquifer, serves as a source of water for municipal and agricultural users in the area. The city of Wichita has used the Equus Beds aquifer as one of its primary water sources since the 1940s. The aquifer in and around Wichita's well field reached historically low water levels in 1993, prompting the city to adopt new water-use and conservation strategies to ensure future water supply needs were met. Part of the plan was to initiate a managed aquifer recharge program called the Equus Beds Aquifer Storage and Recovery project. The goal of the managed aquifer recharge program is to artificially recharge the Equus Beds aquifer with treated water from the Little Arkansas River. As part of the Equus Beds Aquifer Storage and Recovery project, the city of Wichita and the U.S. Geological Survey have partnered in a long-term cooperative study to monitor and describe the quantity and quality of the water in the Equus Beds aquifer and the Little Arkansas River.

The city of Wichita, the Equus Beds Groundwater Management District No. 2, the Kansas Department of Agriculture-Division of Water Resources, and the U.S. Geological Survey collected groundwater levels in numerous wells screened in the Equus Beds aquifer in the area in and around Wichita's well field in January 2016. The measurements were used to interpolate potentiometric surfaces for shallow and deep parts of the aquifer in the study area. These potentiometric surfaces were compared with potentiometric surfaces from previous years to estimate changes in water levels and storage volume in the study area.

Groundwater levels were generally higher in January 2016 than they were in January 2015. On average, in January 2016, groundwater levels in the shallow part of the aquifer were about 3.4 feet higher and groundwater levels in the deep part of the aquifer were about 3.8 feet higher than in January 2015. The volume of water stored in the study area decreased by about 74,000 acre-feet between predevelopment (the time period before substantial pumpage began in the 1940s) and January 2016; increased by about 121,000 acre-feet between the historic low in 1993 and January 2016; and increased by about 61,000 acre-feet between January
2015 and January 2016. About 62 percent of the storage volume lost between predevelopment and 1993 has been recovered. The increase in storage volume from January 2015 to January 2016 can probably be attributed to less pumping by the city of Wichita and irrigators, more recharge due to higher-than-average precipitation, and higher volumes of artificial recharge in 2015.

\section{Introduction}

The Equus Beds aquifer, which is part of the High Plains aquifer, is an important source of water for municipal and agricultural users in south-central Kansas (Equus Beds Groundwater Management District No. 2, 2008). The U.S. Geological Survey (USGS) and the city of Wichita, Kansas, have been engaged in a long-term cooperative partnership to study the quantity and quality of water in the Equus Beds aquifer and the Little Arkansas River since city well field operations began in the 1940s. The central Wichita well field (WWF) (fig. 1) in the Equus Beds aquifer is one of the primary water-supply sources for the city of Wichita. The aquifer reached historically low water levels in 1993, prompting the city to adopt the Integrated Local Water Supply Plan (ILWSP) (Warren and others, 1995). The ILWSP included plans to increase use of surface water from Cheney Reservoir and increase water-conservation efforts, as well as a plan to help ensure adequate future water supply called the Equus Beds Aquifer Storage and Recovery (ASR) project. The goal of the ASR project is to artificially recharge the Equus Beds aquifer to increase aquifer storage and to allow for later recovery of the groundwater. This is accomplished by withdrawing water from the Little Arkansas River, treating the water using drinking-water quality standards as a guideline, and then injecting the water through wells or allowing it to infiltrate through recharge basins into the aquifer. Increases in storage within an area called the basin storage area (BSA) (fig. 1) attributable to the ASR project are credited to the city of Wichita by the State of Kansas, and those credits can be exchanged for the right to pump volumes of water from the aquifer greater than the city's normal annual water right. The increases in storage attributable to the ASR project are 


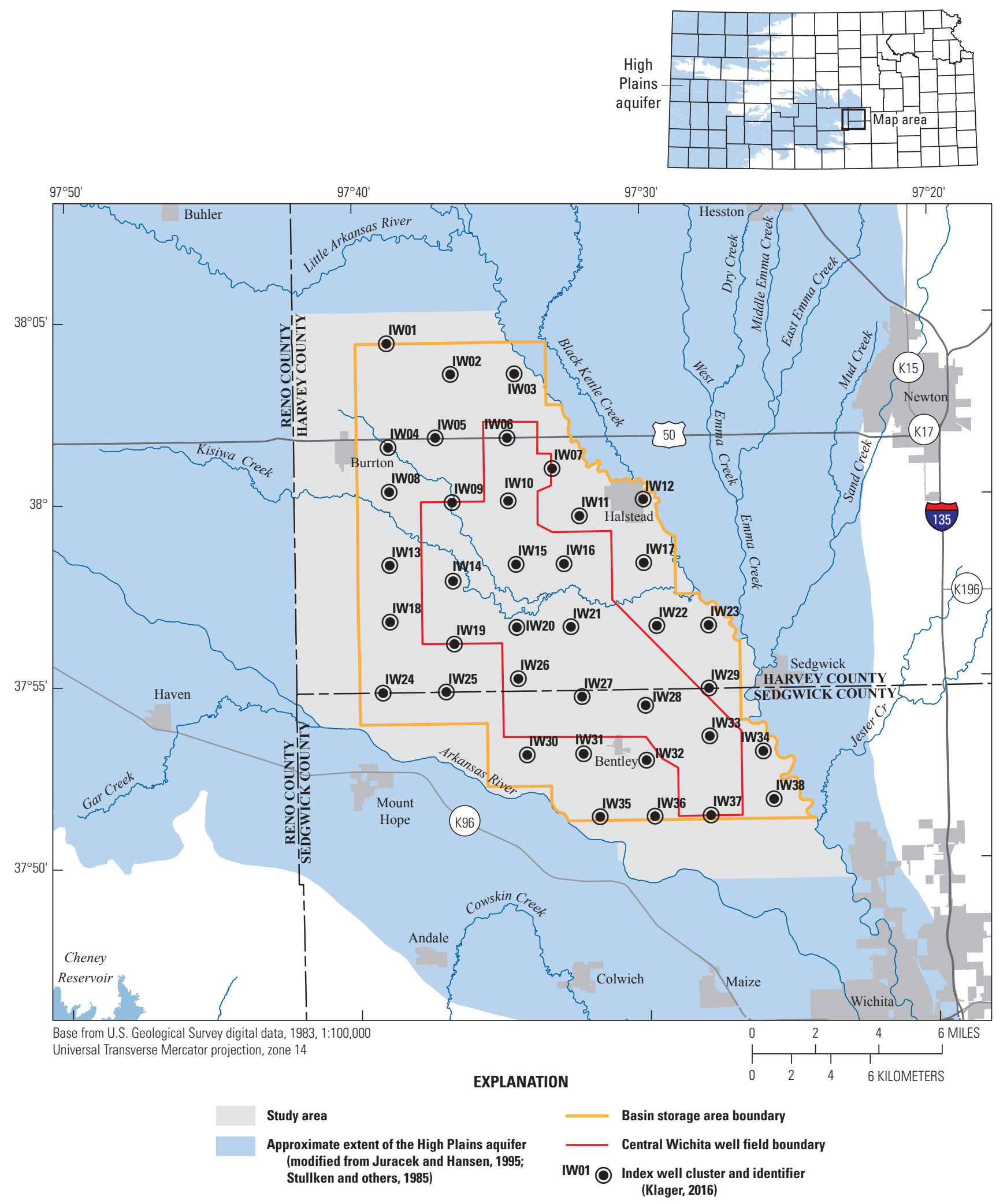

Figure 1. Location of the study area near Wichita, Kansas. 
estimated using a groundwater-flow model (Kelly and others, 2013). The BSA is divided into 38 index cells and the groundwater-flow model is used to calculate the effects of ASR project recharge on the flow budget of each cell. Within each index cell there is a cluster of two index wells, one shallow and one deep, which are used for monitoring water quantity and quality in the aquifer. Credits accumulated during wet years can be used during periods of drought when the city's other primary water source, Cheney Reservoir, might not have the available storage to meet the city's normal demand (City of Wichita, [2007?]).

\section{Purpose and Scope}

The purpose of this report is to present the results of numerous groundwater-level measurements from wells screened in the Equus Beds aquifer near Wichita, Kans., in January 2016. Potentiometric surfaces were interpolated from the groundwater levels for the shallow and deep parts of the aquifer, and maps of the potentiometric surfaces are presented in this report. The potentiometric-surface maps were used to estimate storage-volume change in the study area between predevelopment (the time period before substantial pumpage began in the area, defined in this report as before 1940) and January 2016; the historic low in 1993 and January 2016; and January 2015 and January 2016. Potentiometric surfaces were used to generate maps showing the spatial distributions of estimated groundwater-level change between January 2015 and January 2016; predevelopment and 1993; and 1993 and January 2016 in the study area, which are also presented in this report.

\section{Description of Study Area}

The study area (fig. 1) is located in south-central Kansas, northwest of the city of Wichita. The study area is within the boundary of the Equus Beds aquifer, which is the easternmost part of the High Plains aquifer in Kansas. The study area is located between the Arkansas and Little Arkansas Rivers, overlying 189 square miles $\left(\mathrm{mi}^{2}\right)$ of southwest Harvey and northwest Sedgwick Counties. The WWF is in the central part of the study area, with an area of about $55 \mathrm{mi}^{2}$. Most of the BSA is within the study area (the northeast corner of the BSA extends outside of the study area), with a total area of about $141 \mathrm{mi}^{2}$.

The study area has a continental climate characterized by cold winters and hot summers. In 2015, at a National Weather Service weather station at the Dwight D. Eisenhower National Airport in Wichita, the maximum recorded temperature was 102 degrees Fahrenheit $\left({ }^{\circ} \mathrm{F}\right)$ on September 7 , and the minimum temperature recorded was $0{ }^{\circ} \mathrm{F}$ on January 7 (National Oceanic and Atmospheric Administration, 2016a). In 2015, the average total precipitation across the study area was about 41.8 inches (National Oceanic and Atmospheric Administration, 2016b). The 30-year average annual precipitation in the study area is about 32.7 inches, based on observed precipitation datasets from the National Weather Service Advanced Hydrologic Prediction Service (National Oceanic and Atmospheric Administration, 2016b).

In the study area, the Equus Beds aquifer consists mostly of Quaternary-age sand and gravel with some interbedded clay. There are dune sands in the northern part of the study area that form a topographic high (Williams and Lohman, 1949). The average aquifer thickness is estimated to be about $110 \mathrm{feet}(\mathrm{ft})$, with the thickest part of the aquifer at about $330 \mathrm{ft}$ (Kelly and others, 2013). Groundwater-flow direction is generally west to east, with the Arkansas River discharging into the aquifer in the west and the aquifer discharging into the Little Arkansas River in the east.

Land use is mostly crop production and grasslands. Based on data compiled by the Kansas Applied Remote Sensing Program (KARS) in 2005, land cover was about 73 percent cropland and about 20 percent grassland, with the remainder split between woodlands, urban lands, water, and conservation reserve program lands (Kansas Applied Remote Sensing Program, 2010).

Most groundwater use in the study area is for municipal or agricultural purposes. Outside of the WWF, the primary use is irrigation; inside the WWF, the primary use is municipal. In the study area, irrigation typically has an inverse relationship with precipitation, with higher withdrawals in years of lower precipitation (fig. 2). Before 1993, the municipal water use in the WWF was about 40,000 acrefeet per year (acre-ft/yr). With the adoption of the ILWSP, municipal groundwater use from the WWF decreased to about 20,000 acre-ft/yr by the late 1990s. The city of Wichita substantially decreased pumping from the WWF during 2014 and 2015 (fig. 2; Kansas Geological Survey and Kansas Department of Agriculture, 2016; Ginger Pugh, Kansas Department of Agriculture, written commun., 2016).

\section{Previous Studies}

Water levels and storage changes in the study area have been documented in previous years (Hansen, 2009, 2011, 2012; Hansen and Aucott, 2010; Hansen and others, 2013, 2014; Whisnant and others, 2015). Hansen and others (2013) mapped the 1993 historic low water levels. Kelly and others (2013) developed a groundwater-flow model of the Equus Beds aquifer for the purpose of estimating storage changes in the BSA attributable to the ASR project artificial recharge. Water quality in the study area has been documented by Ziegler and others (2010) and Tappa and others (2015).

\section{Methods}

This section describes the methods used to collect and process the groundwater-level data used in this report, interpolate potentiometric surfaces, and estimate changes in 


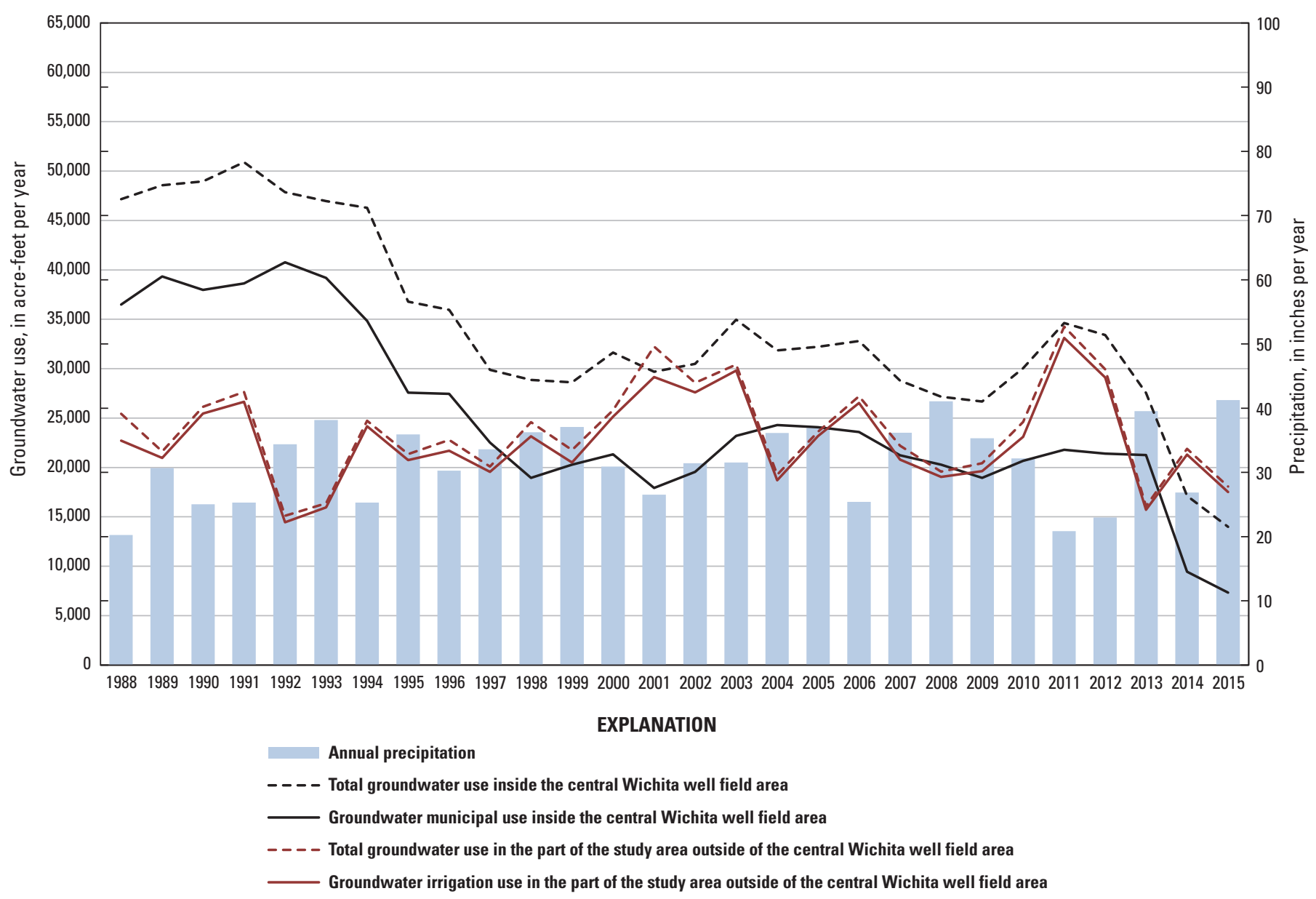

Figure 2. Annual groundwater use in the central Wichita well field area and the rest of the study area, and average annual precipitation in the study area, 1988 through 2015 (Water-use data are from Kansas Geological Survey and Kansas Department of Agriculture, 2016; precipitation data are from the National Oceanic and Atmospheric Administration, 2016a, 2016b) (modified from Hansen and others, 2014; Whisnant and others, 2015).

aquifer storage volume in the study area. These methods are similar to those described in previous reports (Whisnant and others, 2015; Hansen and others, 2014; Hansen and others, 2013).

\section{Groundwater-Level Measurements}

Groundwater levels were collected in numerous wells screened in the Equus Beds aquifer in and around the study area (fig. 1) from January 4 through January 29, 2016. The water levels were measured by the city of Wichita, the Equus Beds Groundwater Management District No. 2 (GMD2), the Kansas Department of Agriculture-Division of Water Resources (KDA-DWR), and the U.S. Geological Survey. Pumping from the WWF was paused in mid-December to allow the groundwater levels to recover to static or nearstatic conditions prior to the measurements. Groundwaterlevel measurements were completed following the procedures described in Cunningham and Schalk (2011). The groundwater data are stored in the U.S. Geological Survey's
National Water Information System (NWIS). These data are available to the public through the NWIS web interface (U.S. Geological Survey, 2016b). A total of 477 measurements collected in and around the study area during January 2016 were used for this report. The measurements used were selected based on whether the well depth was known and whether the well was needed to achieve adequate spatial coverage of the study area to perform an interpolation of the head values for the potentiometric-surface maps of the shallow and deep parts of the aquifer. The point measurements used to perform the analyses described in this report are compiled in a data release (Klager, 2016).

\section{Shallow and Deep Parts of the Aquifer}

The Equus Beds aquifer is thought to be unconfined in most of the study area; however, some shallow and deep wells that are clustered together have substantial differences in measured water levels, indicating confinement or semi-confinement of the deeper zone. Therefore, wells were 
classified as being screened in the shallow or deep part of the aquifer based on two criteria. First, many wells have already been assigned to the shallow or deep layer of the aquifer and are named accordingly. For instance, each ASR index monitoring well cluster has a shallow and deep well, with well names ending in " $\mathrm{A}$ " or " $\mathrm{C}$," indicating that they are screened in shallow or deep parts of the aquifer, respectively. Second, if no indication is given in the well name, wells are classified into shallow and deep parts of the aquifer based on well depth. Ziegler and others (2010) classified wells less than $80 \mathrm{ft}$ deep as shallow wells and wells $80 \mathrm{ft}$ deep or deeper as deep wells, and this convention is used in this report.

\section{Interpolation of Potentiometric Surfaces}

The shallow and deep potentiometric surfaces were interpolated using the ArcGIS tool "Topo to Raster" (Esri, 2014) in a geographic information system (GIS). The initial surface interpolations used only the point groundwater-level measurements. Because the initial interpolations had some features that were unrealistic for the potentiometric surfaces, the initial surfaces were contoured, and the contours were manually adjusted based on hydrologic expertise. The Topo to Raster tool was used to reinterpolate the surfaces using the point groundwater-level measurement data and the manually adjusted contours to produce the final potentiometric surfaces. The final interpolated rasters and potentiometric contour files are available as part of a data release (Klager, 2016).

\section{Estimation of Storage-Volume Change}

Changes in saturated aquifer volume were estimated by calculating the groundwater-level change between the shallow January 2016 potentiometric surface and past shallow potentiometric surfaces in each raster cell in the GIS. Groundwater-level differences were then multiplied by the area of the raster cell to calculate the change in saturated aquifer volume in each cell. Changes in saturated aquifer volume in all cells were summed to calculate the change in saturated volume of the aquifer in the study area. Changes in storage volume were estimated for predevelopment to January 2016, the historic low of 1993 to January 2016, and January 2015 to January 2016. The January 2015 potentiometric surface was estimated by Whisnant and others (2015). The 1993 and predevelopment potentiometric surfaces were estimated by Hansen and others (2013).

To convert a change in saturated aquifer volume to a change in volume of water stored in the aquifer, the change in saturated volume must be multiplied by a specific yield value. Specific yield is the volume of water per unit bulk aquifer volume that will drain out under the force of gravity (Meinzer, 1923). Previous studies (Hansen and others, 2013, 2014; Whisnant and others, 2015) used a specific yield value of 0.15 , and that value was used in this report. This value was determined from calibration of a groundwater-flow model of the Equus Beds aquifer by Kelly and others (2013). Earlier reports (Hansen and Aucott, 2010; Hansen, 2009, 2011,2012 ) had used a specific yield value of 0.20 .

\section{Potentiometric Surface Maps, January 2016}

The potentiometric surfaces produced using the January 2016 groundwater-level measurement data are presented in figures 3 and 4 . The groundwater-flow direction, as indicated by the head gradients in both shallow and deep maps, is west to east. The maximum head in the shallow surface was $1,475.89 \mathrm{ft}$, located in the northwestern part of the study area near monitoring well IW01A in the northwestern corner of the BSA. The minimum head value in the shallow surface was $1,325.95 \mathrm{ft}$ in the southeastern corner of the study area near the Little Arkansas River. The maximum head value in the deep potentiometric surface was $1,443.93 \mathrm{ft}$ at the western boundary of the study area south of Burrton. The minimum head value in the deep potentiometric surface was $1,326.38 \mathrm{ft}$, located in the southeastern corner of the study area near the Little Arkansas River.

\section{Groundwater-Level and Storage- Volume Changes in the Equus Beds Aquifer}

Groundwater levels were generally higher in the study area in January 2016 than they were in January 2015 (fig. 5). Multiple factors contributed to increased levels, including increased precipitation in 2015 and less pumping by both agricultural and municipal users in 2015 . The average groundwater-level increase in the shallow part of the aquifer between January 2015 and January 2016 was $3.37 \mathrm{ft}$ in the study area, $3.82 \mathrm{ft}$ in the BSA, and $4.50 \mathrm{ft}$ in the WWF. These average groundwater-level changes were calculated by averaging the differences between the shallow potentiometric surfaces from January 2015 and January 2016 in the GIS. The groundwater-level changes in the shallow part of the aquifer are used to estimate changes in storage volume.

The volume of water stored in the study area, the BSA, and the WWF all increased from January 2015 to January 2016 . The storage volume increased by about 61,000 acrefeet (acre-ft) in the study area, about 51,000 acre- $\mathrm{ft}$ in the BSA, and about 24,000 acre-ft in the WWF. The storage increase can most likely be attributed to lower volumes pumped by the city of Wichita (about 7,400 acre-ft in 2015 compared to about 9,700 acre-ft in 2014) (Ginger Pugh, Kansas Department of Agriculture, written commun., 2016) 


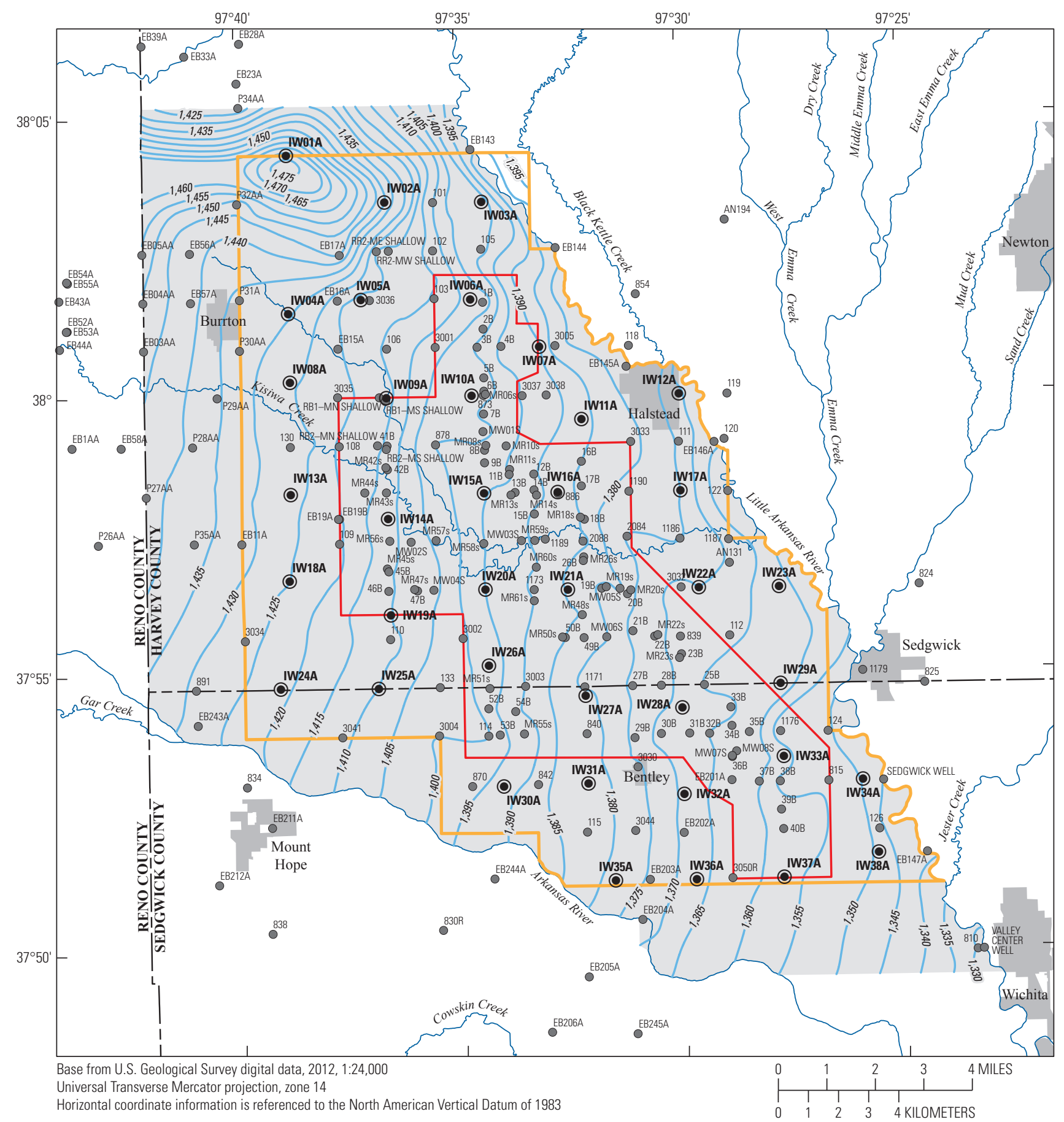

EXPLANATION

Study area

Basin storage area boundary

Central Wichita well field boundary
- 1,440 - Potentiometric contour - Shows the altitude at which water would have stood in tightly cased wells in the shallow part of the Equus Beds aquifer, January 2016. Contour interval of 5 feet. Vertical Datum is North American Vertical Datum of 1988. Groundwater-flow direction is perpendicular to potentiometric contours from high to low values

EB10A

Shallow monitoring well and identifier

Figure 3. Potentiometric surface of the shallow part of the Equus Beds aquifer study area, south-central Kansas, January 2016. 


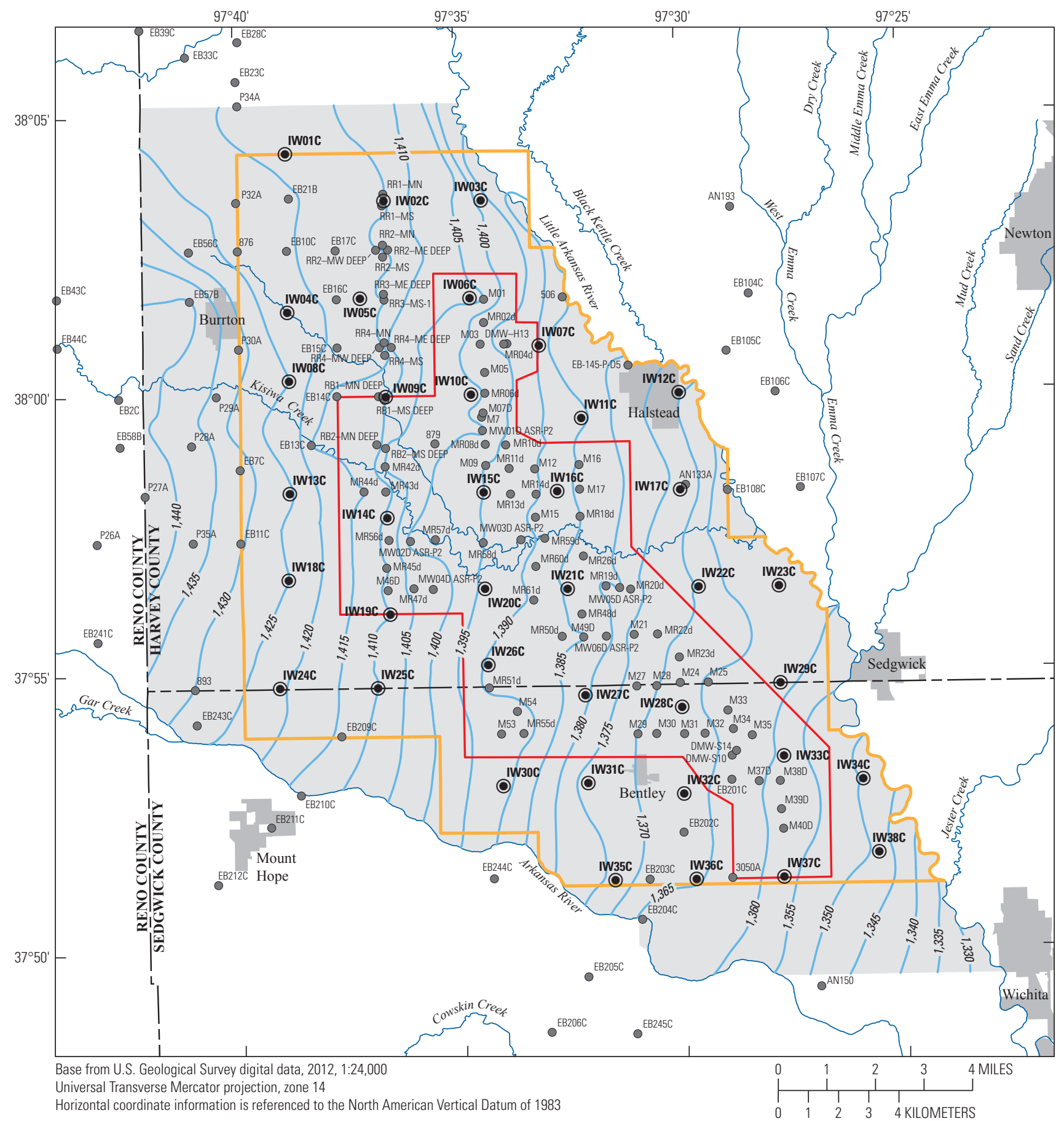

EXPLANATION

Study area

Basin storage area boundary

Central Wichita well field boundary

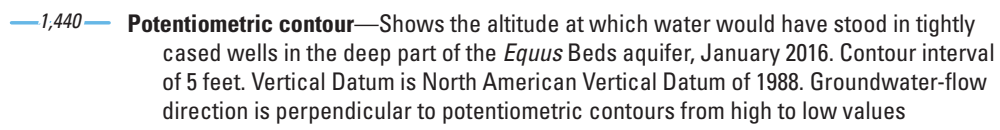

$\overbrace{}^{E B 10 C}$ Deep monitoring well and identifier

IW01C Deep index monitoring well and identifier (Klager, 2016)

Figure 4. Potentiometric surface of the deep part of the Equus Beds aquifer study area, south-central Kansas, January 2016. 


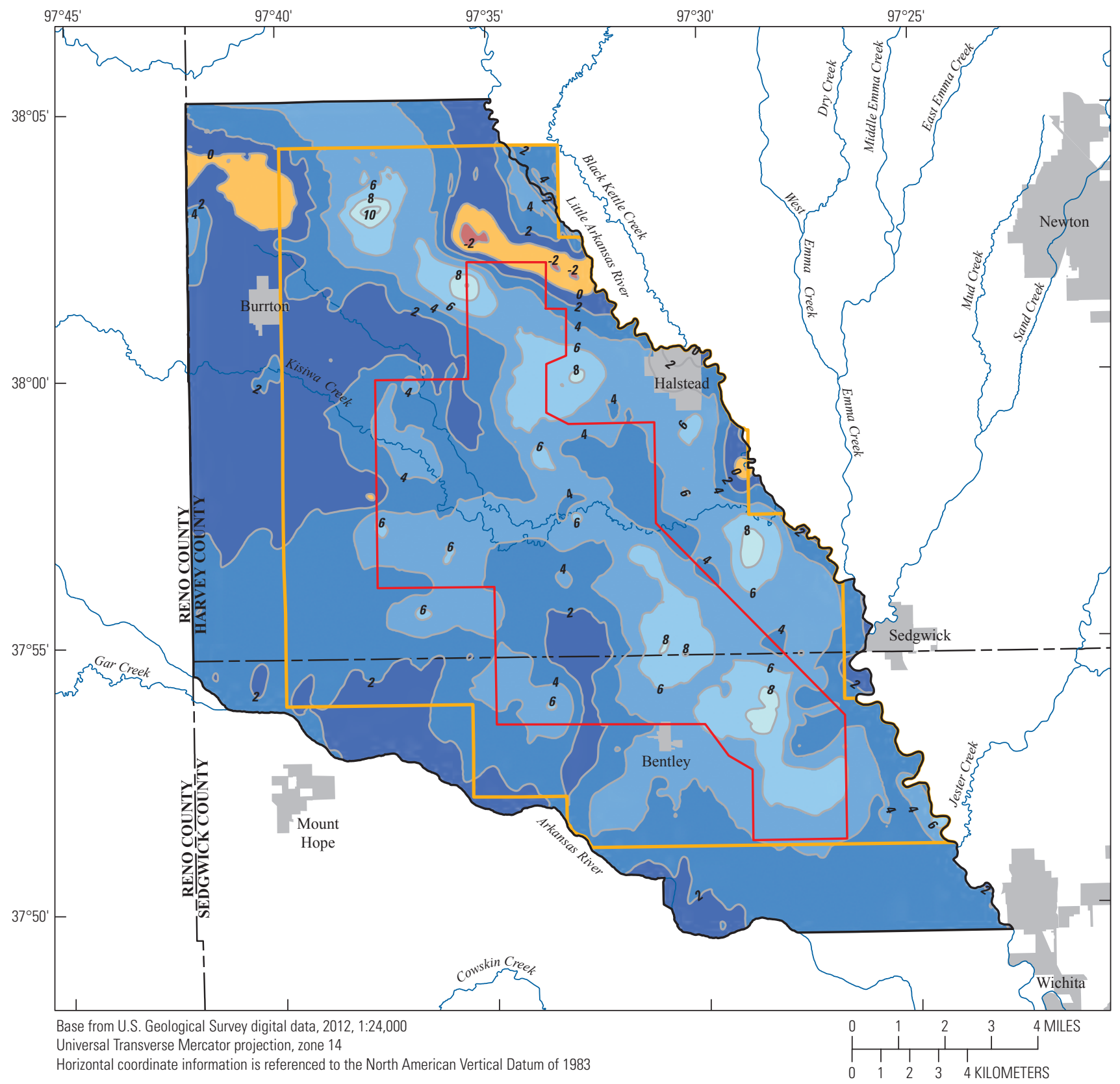

EXPLANATION

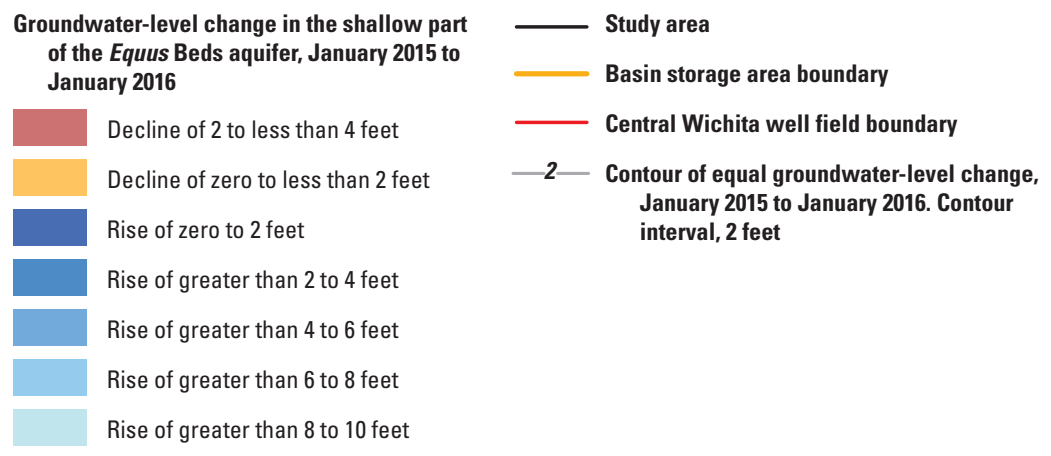

Figure 5. Groundwater-level change in the shallow part of the Equus Beds aquifer study area in south-central Kansas, January 2015 to January 2016. 
and higher precipitation leading to more recharge of the aquifer (about 41.3 inches of precipitation in 2015 compared to about 27.7 inches in 2014, with a 30 -year average precipitation of 32.7 inches across the study area) (National Oceanic and Atmospheric Administration, 2016b). There was also an increased volume of artificially recharged water in 2015. The ASR project recharged about 1,770 acre-ft in
2015 compared to about 950 acre-ft in 2014 (U.S. Geological Survey, 2016a). The January 2016 storage volume in the study area was about 74,000 acre-ft less than the predevelopment storage volume. The storage-volume increase since the historic low of 1993 was about 121,000 acre-ft, a 62-percent recovery of the storage lost from predevelopment to 1993 (table 1, figs. 6-9).

Table 1. Storage-volume changes in the Equus Beds aquifer near Wichita, Kansas, since predevelopment (pre 1940) and since 1993 to January 2016 for the study area, the basin storage area, and the central Wichita well field area.

[--, not applicable]

\begin{tabular}{|c|c|c|}
\hline \multirow{2}{*}{ End of time period } & \multicolumn{2}{|c|}{ Storage-volume changes } \\
\hline & Since predevelopment (acre-feet) & Since 1993 (acre-feet) \\
\hline \multicolumn{3}{|c|}{ Study area } \\
\hline 1993 & ${ }^{1}-195,000$ & -- \\
\hline January 2012 & ${ }^{1}-125,000$ & ${ }^{2} 70,000$ \\
\hline July 2012 & ${ }^{1}-175,000$ & ${ }^{2} 20,000$ \\
\hline January 2013 & ${ }^{1}-154,000$ & 241,000 \\
\hline January 2014 & ${ }^{1}-116,000$ & ${ }^{2} 79,000$ \\
\hline January 2015 & ${ }^{1}-135,000$ & ${ }^{1} 60,000$ \\
\hline January 2016 & $-74,000$ & 121,000 \\
\hline \multicolumn{3}{|c|}{ Basin storage area } \\
\hline 1993 & ${ }^{1}-188,000$ & -- \\
\hline January 2012 & ${ }^{1}-112,000$ & ${ }^{2} 76,000$ \\
\hline July 2012 & ${ }^{1}-155,000$ & 233,000 \\
\hline January 2013 & ${ }^{1}-134,000$ & ${ }^{2} 54,000$ \\
\hline January 2014 & ${ }^{1}-108,000$ & ${ }^{2} 80,000$ \\
\hline January 2015 & ${ }^{1}-119,000$ & ${ }^{1} 69,000$ \\
\hline January 2016 & $-68,000$ & 120,000 \\
\hline \multicolumn{3}{|c|}{ Central Wichita well field area } \\
\hline 1993 & ${ }^{1}-121,000$ & -- \\
\hline January 2012 & ${ }^{1}-59,000$ & ${ }^{2} 62,000$ \\
\hline July 2012 & ${ }^{1}-74,000$ & ${ }^{2} 47,000$ \\
\hline January 2013 & ${ }^{1}-69,000$ & ${ }^{2} 52,000$ \\
\hline January 2014 & ${ }^{1}-63,000$ & ${ }^{2} 58,000$ \\
\hline January 2015 & ${ }^{1}-65,000$ & ${ }^{1} 56,000$ \\
\hline January 2016 & $-41,000$ & 80,000 \\
\hline
\end{tabular}

${ }^{1}$ Storage-volume change previously reported in Whisnant and others (2015).

${ }^{2}$ Storage-volume change previously reported in Hansen and others (2014). 


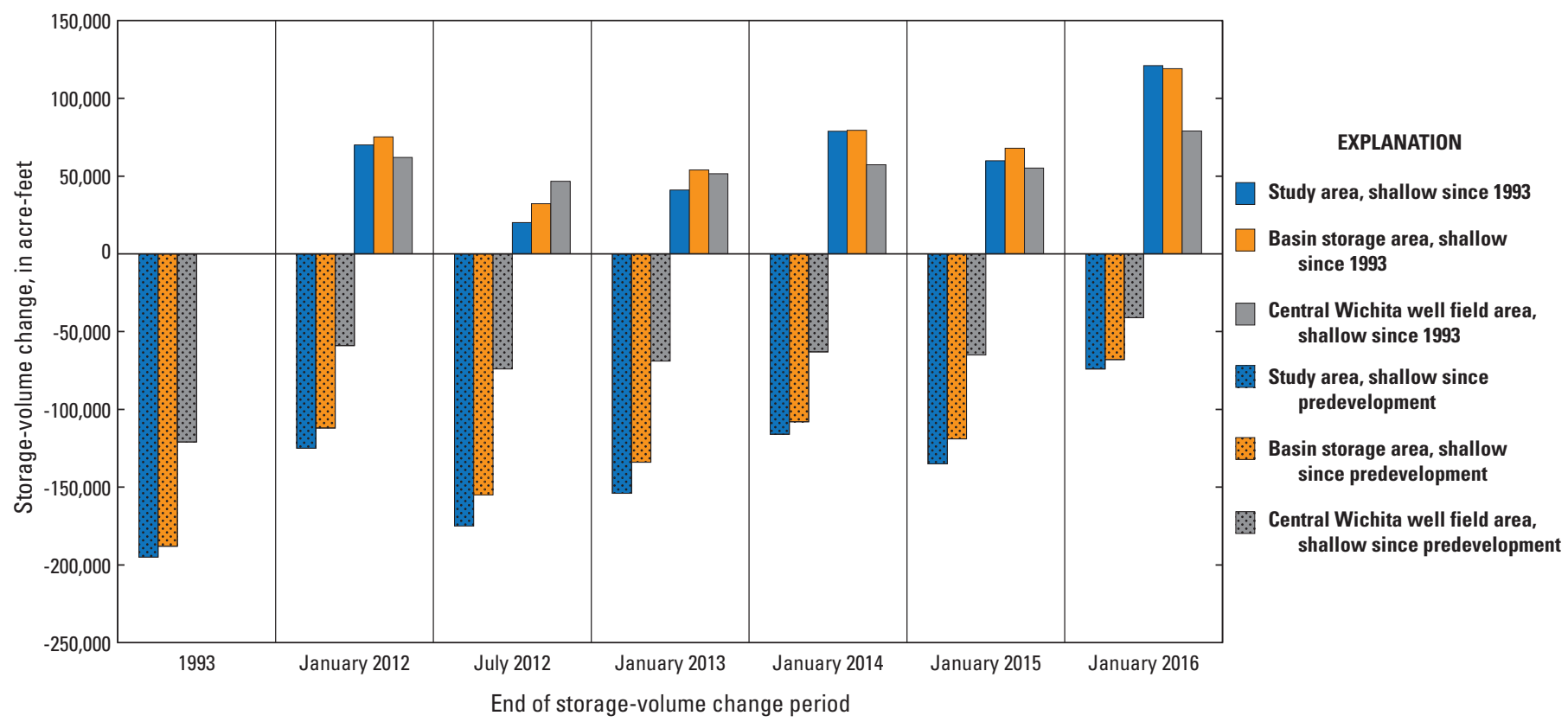

Figure 6. Estimates of storage-volume change since predevelopment (before 1940) and 1993 in the Equus Beds aquifer study area. 


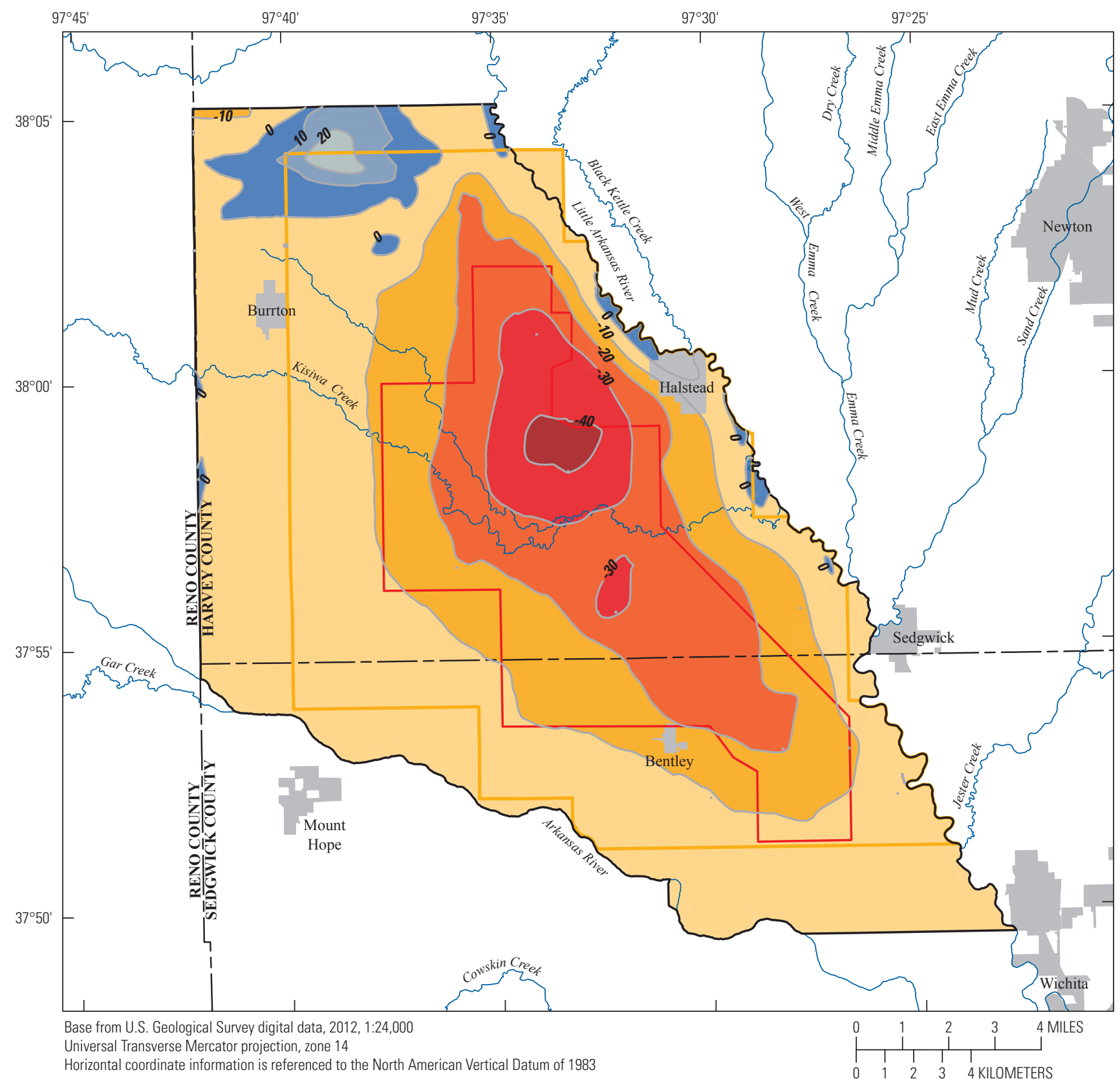

EXPLANATION

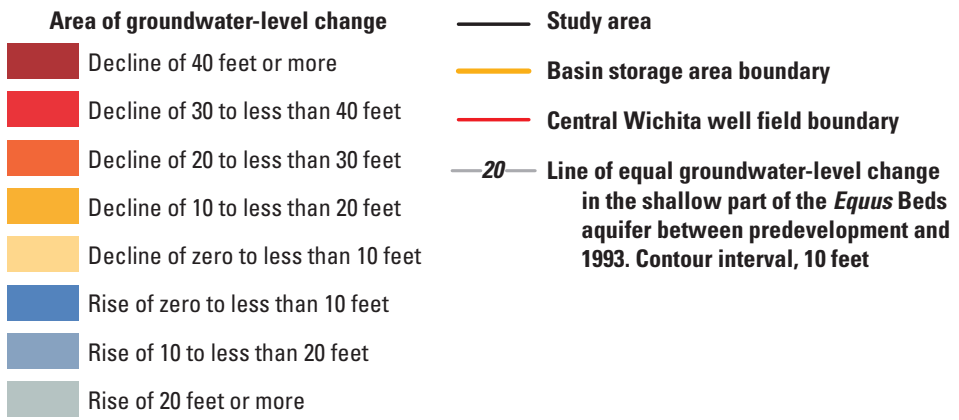

Figure 7. Groundwater-level changes in the Equus Beds aquifer in and around the Wichita well field in south-central Kansas between predevelopment (before 1940) and the historic low of 1993. 


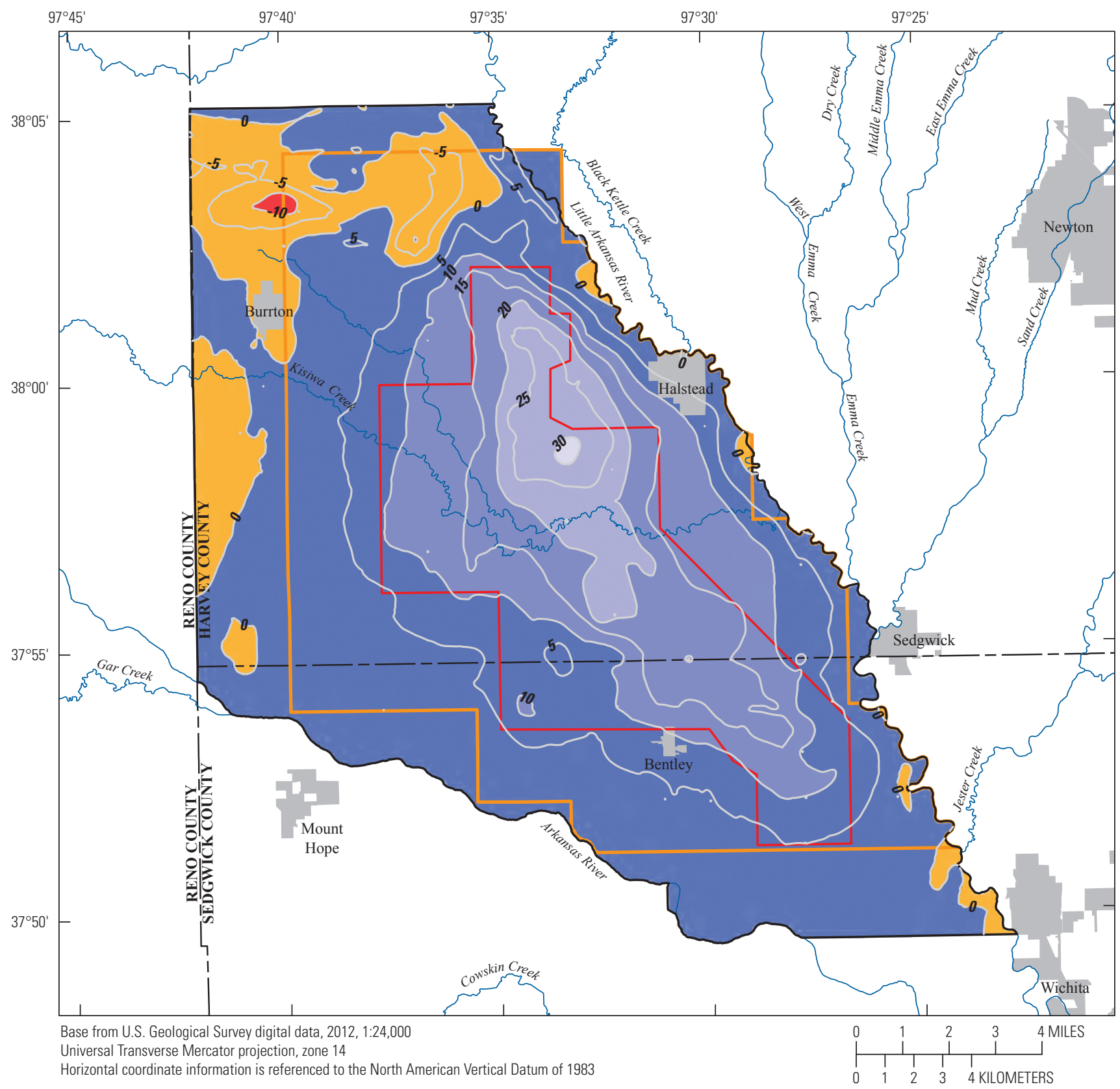

EXPLANATION
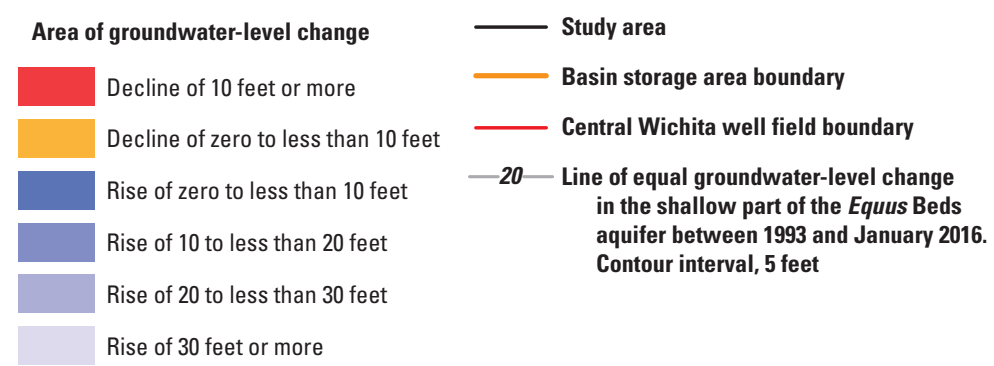

Figure 8. Groundwater-level changes in the shallow part of the Equus Beds aquifer in and around the Wichita well field in southcentral Kansas between 1993 and January 2016. 


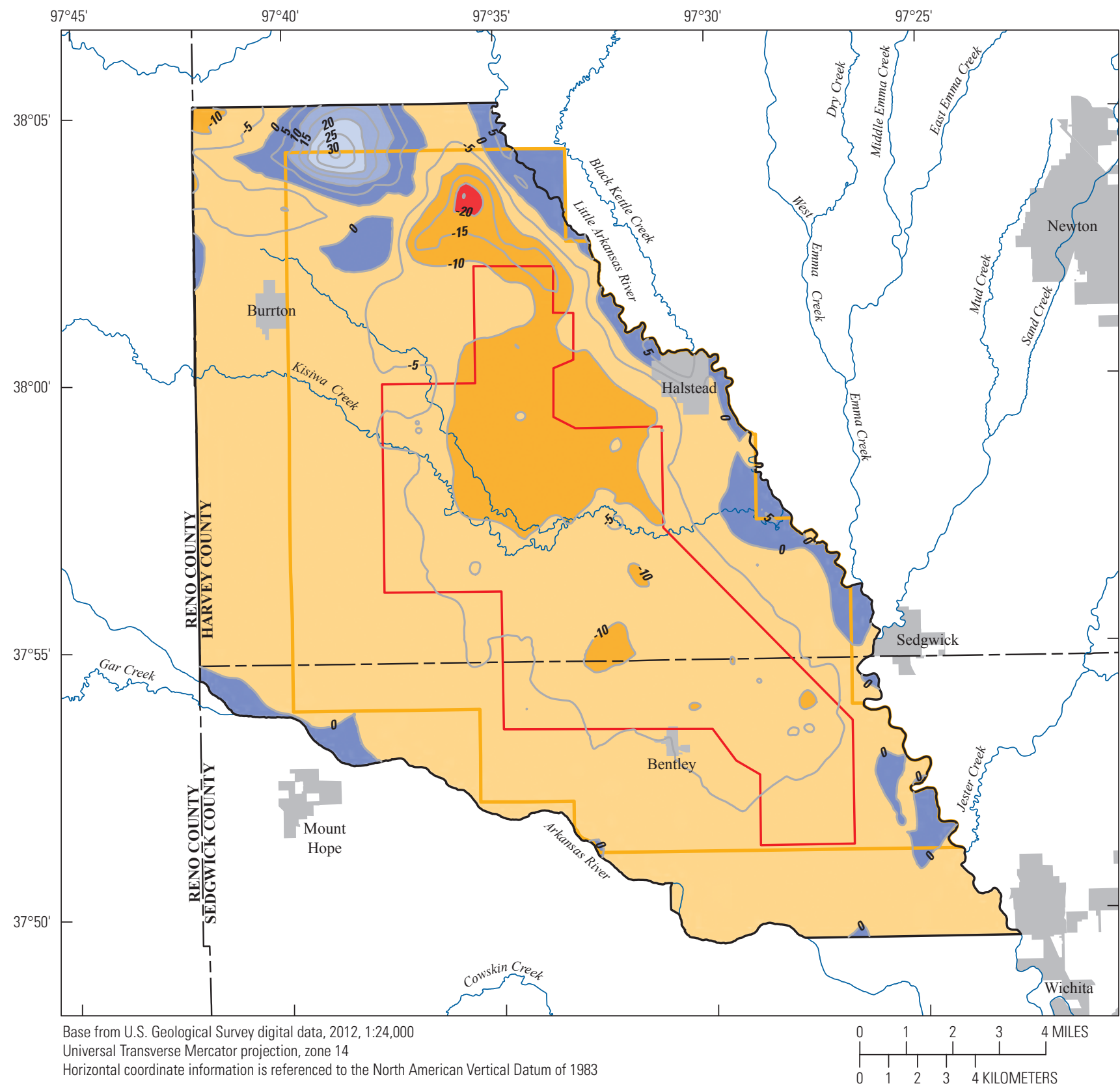

EXPLANATION

\begin{tabular}{|l}
\hline Area of groundwater-level change: \\
Decline of 20 feet or more \\
Decline of 10 to less than 20 feet \\
Decline of zero to less than 10 feet \\
Rise of zero to less than 10 feet \\
Rise of 10 to less than 20 feet \\
Rise of 20 feet or more
\end{tabular}

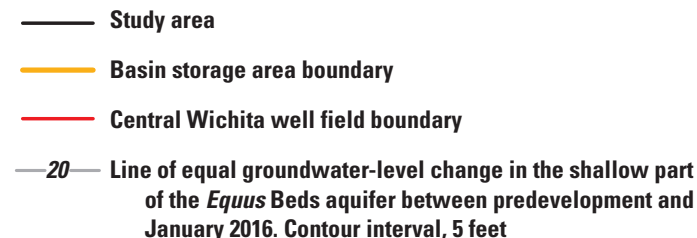
January 2016. Contour interval, 5 feet

Figure 9. Groundwater-level changes in the shallow part of the Equus Beds aquifer in and around the Wichita well field in southcentral Kansas between predevelopment (before 1940) and January 2016. 


\section{Summary}

The Equus Beds aquifer in south-central Kansas is part of the High Plains aquifer that serves as a source of water for municipal and agricultural users in the area. The city of Wichita has used the Equus Beds aquifer as one of its primary water sources since the 1940s. The aquifer in and around Wichita's well field reached historically low water levels in 1993, prompting the city to adopt new water-use and conservation strategies to ensure that future watersupply needs would be met. Part of the plan was to initiate a managed aquifer recharge program called the Equus Beds Aquifer Storage and Recovery project. The goal of the managed aquifer recharge program is to artificially recharge the Equus Beds aquifer with treated water from the Little Arkansas River. As part of the Equus Beds Aquifer Storage and Recovery project, the city of Wichita and the U.S. Geological Survey have partnered in a long-term cooperative study to monitor and describe the quantity and quality of the water in the Equus Beds aquifer and the Little Arkansas River.

In January 2016, the city of Wichita, the Equus Beds Groundwater Management District No. 2, the Kansas Department of Agriculture-Division of Water Resources, and the U.S. Geological Survey collected numerous groundwater levels from wells screened in the Equus Beds aquifer in the area in and around Wichita's well field. The measurements were used to interpolate potentiometric surfaces for shallow and deep parts of the aquifer in the study area. These potentiometric surfaces were compared with potentiometric surfaces from previous years to estimate changes in storage volume in the study area.

Groundwater levels were generally higher in January 2016 than they were in January 2015. On average, groundwater levels in the shallow part of the aquifer were about 3.4 feet higher and groundwater levels in the deep part of the aquifer were about 3.8 feet higher in January 2016 than in January 2015. The volume of water stored in the study area decreased by about 74,000 acre-feet between predevelopment (before substantial pumpage began in the 1940s) and January 2016; increased by about 121,000 acre-feet between the historic low in 1993 and January 2016; and increased by about 61,000 acre-feet between January 2015 and January 2016. About 62 percent of the storage volume lost between predevelopment and 1993 has been recovered. The increase in storage volume from January 2015 to January 2016 can probably be attributed to less pumping by the city of Wichita and irrigators, more recharge due to higher-than-average precipitation, and higher volumes of artificial recharge in 2015.

\section{References Cited}

City of Wichita, [2007?], Wichita area future water supplyA model program for other municipalities: Wichita, Kans., accessed September 19, 2016, at http://www.wichita.gov/ Government/Departments/PWU/UtilitiesDocuments/WICHITA\%20AREA\%20FUTURE\%20WATER\%20SUPPLY.pdf.

Cunningham, W.L., and Schalk, C.W., comps., 2011, Groundwater technical procedures of the U.S. Geological Survey: U.S. Geological Survey Techniques and Methods, book 1, chap. A1, 151 p., accessed November 9, 2016 at https:// pubs.usgs.gov/tm/1a1/.

Esri, 2014, ArcGIS help 10.2, 10.2.1, and 10.2.2-How topo to raster works: Esri, accessed August 11, 2016, at http:// resources.arcgis.com/en/help/main/10.2/index.html\#/How_ Topo_to_Raster_works/009z0000007m000000/.

Equus Beds Groundwater Management District No. 2, 2008, About us: accessed September 19, 2016, at http://www. gmd2.org/AboutUs.html.

Hansen, C.V., 2009, Status of groundwater levels and storage volume in the Equus Beds aquifer near Wichita, Kansas, January 2009: U.S. Geological Survey Scientific Investigations Map 3087, 1 sheet.

Hansen, C.V., 2011, Status of groundwater levels and storage volume in the Equus Beds aquifer near Wichita, Kansas, January 2011: U.S. Geological Survey Scientific Investigations Map 3192, 1 sheet.

Hansen, C.V., 2012, Status of groundwater levels and storage volume in the Equus Beds aquifer near Wichita, Kansas, July 2011: U.S. Geological Survey Scientific Investigations Map 3208, 1 sheet.

Hansen, C.V., and Aucott, W.R., 2010, Status of groundwater levels and storage volume in the Equus Beds aquifer near Wichita, Kansas, January 2006 to January 2010: U.S. Geological Survey Scientific Investigations Report 2010-5231, $47 \mathrm{p}$.

Hansen, C.V., Lanning-Rush, J.L., and Ziegler, A.C., 2013, Revised shallow and deep water-level and storage-volume changes in the Equus Beds aquifer near Wichita, Kansas, predevelopment to 1993: U.S. Geological Survey Scientific Investigations Report 2013-5170, 18 p. 
Hansen, C.V., Whisnant, J.A., and Lanning-Rush, J.L., 2014, Status of groundwater levels and storage volume in the Equus Beds aquifer near Wichita, Kansas, 2012 to 2014: U.S. Geological Survey Scientific Investigations Report 2014-5185, 39 p.

Juracek, K.E., and Hansen, C.V., 1995, Digital maps of the extent, base, top, and 1991 potentiometric surface of the High Plains aquifer in Kansas: U.S. Geological Survey Open-File Report 95-758, scales 1:500,000 and $1: 1,000,000$.

Kansas Applied Remote Sensing Program, 2010, 2005 Kansas land cover patterns (Level I and Level IV) data: Kansas Biological Survey, University of Kansas, accessed July 18, 2016, at http://kars.ku.edu/research/2005-kansas-landcover-patterns-level-iv/.

Kansas Geological Survey and Kansas Department of Agriculture, 2016, Water Information Management and Analysis System (WIMAS) for the Web: Kansas Department of Agriculture, Division of Water Resources database, accessed November 9, 2016, at http://hercules.kgs.ku.edu/geohydro/ wimas/index.cfm.

Kelly, B.P., Pickett, L.L., Hansen, C.V., and Ziegler, A.C., 2013, Simulation of groundwater flow, effects of artificial recharge, and storage volume changes in the Equus Beds aquifer near the city of Wichita, Kansas well field, 19392008: U.S. Geological Survey Scientific Investigations Report 2013-5042, 90 p. [Also available at http://pubs.usgs. gov/sir/2013/5042/.]

Klager, B.J., 2016, Groundwater levels in the Equus Beds aquifer near Wichita, Kansas, January 2016: U.S. Geological Survey data release, accessed December 2016, January 2016: U.S. Geological Survey data release accessed December 2016 at https://dx.doi.org/10.5066/F7KP809V.

Meinzer, O.E., 1923, Outline of ground-water hydrology, with definitions: U.S. Geological Survey Water-Supply Paper 494, $71 \mathrm{p}$.

National Oceanic and Atmospheric Administration, 2016a, Climate data online: Asheville, NC, National Centers for Environmental Information, accessed July 18, 2016, at https:/www.ncdc.noaa.gov/cdo-web/.
National Oceanic and Atmospheric Administration, 2016b, Gridded observed precipitation data: National Weather Service, accessed August 3, 2016, at http://water.weather.gov/ precip/download.php.

Stullken, L.E., Watts, K.R., and Lindgren, R.J., 1985, Geohydrology of the High Plains aquifer, western Kansas: U.S. Geological Survey Water-Resources Investigations Report 85-4198, 86 p. [Also available at http://pubs.er.usgs.gov/ publications/wri854198.]

Tappa, D.J., Lanning-Rush, J.L., Klager, B.J., Hansen, C.V., and Ziegler, A.C., 2015, Water quality of the Little Arkansas River and Equus Beds aquifer before and concurrent with large-scale artificial recharge, south-central Kansas, 1995-2012: U.S. Geological Survey Scientific Investigations Report 2015-5023, 67 p.

U.S. Geological Survey, 2016a, Equus beds water recharge: U.S. Geological Survey Web page, accessed August 3, 2016, at http://ks.water.usgs.gov/water-recharge.

U.S. Geological Survey, 2016b, National Water Information System_-Web Interface_-USGS water data for Kansas: U.S. Geological Survey database, accessed November 17, 2016, at http://waterdata.usgs.gov/ks/nwis.

Warren, D.R., Blain, G.T., Shorney, F.L., and Klein, L.J., 1995, IRP - A case study from Kansas: Journal of the American Water Works Association, p. 57-71.

Whisnant, J.A., Hansen, C.V., and Eslick, P.J., 2015, Groundwater-level and storage-volume changes in the Equus Beds aquifer near Wichita, Kansas, predevelopment through January 2015: U.S. Geological Survey Scientific Investigations Report 2015-5121, 27 p.

Williams, C.C., and Lohman, S.W., 1949, Geology and ground-water resources of a part of south-central Kansas, with special reference to the Wichita municipal water supply: Kansas Geological Survey Bulletin 79, 455 p.

Ziegler, A.C., Hansen, C.V., and Finn, D.A., 2010, Water quality in the Equus Beds aquifer and the Little Arkansas River before implementation of large-scale artificial recharge, south-central Kansas, 1995-2005: U.S. Geological Survey Scientific Investigations Report 2010-5023, 143 p. 
Publishing support provided by:

Rolla Publishing Service Center

For additional information concerning this publication, contact:

Director, USGS Kansas Water Science Center

4821 Quail Crest Place

Lawrence, KS 66049

(785) 842-9909

Or visit the Kansas Water Science Center Web site at: http://ks.water.usgs.gov 



\section{$\frac{\mathbb{2}}{3}$}

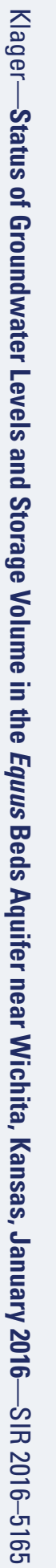

